\title{
LA VIDA DE MAHOMA EN LAS FUENTES CRISTIANAS MEDIEVALES: LUCAS DE TUY
}

\section{Emma Falque Rey}

\begin{abstract}
A Mª Eugenia Gálvez y Francisco Presedo, juntos en el recuerdo.
\end{abstract}

El interés que suscitó en la Edad Media la figura de Mahoma hizo que también los autores cristianos que escribieron en latín, se ocuparan del personaje, visto obviamente desde una perspectiva distinta a la de las fuentes árabes. Mi propósito es ofrecer en estas páginas la edición y traducción de una Vida de Mahoma, incluida por Lucas de Tuy en su Chronicon mundi que puede resultar de utilidad para los arabistas pues no hay edición ni traducción recientes de este texto ${ }^{1}$ y es un indicio de lo que a principios del s.XIII sabían --o querían saber-- los cristianos del norte de la península sobre Mahoma.

Los necesarios límites impuestos a este trabajo no me permiten ni comparar este interesantísimo texto de Lucas de Tuy con otra vida del profeta escrita varios siglos antes (s.IX) por un autor mozárabe, Eulogio de Córdoba, incluida en su Liber Apologeticus martyrum $^{2}$, ni extenderme en el tratamiento que hacen de la Vida de Mahoma otras fuentes cristianas $^{3}$. También por razones de espacio he prescindido para el texto del aparato crítico, pues espero que los estudiosos del Latín Medieval puedan pronto tener entre sus manos la edición crítica de esta obra ${ }^{4}$. Para los nombres propios sigo la transcripción del texto latino.

\footnotetext{
${ }^{1}$ La única edición, hasta ahora, del Chronicon mundi es la de J. de Mariana publicada por A. Schott en el tomo IV de la Hispania Illustrata, Frankfurt, 1608, pp. 1-116. Es poco conocido que esta edición es de Mariana, pues la información que da A. Schott en el prólogo es muy escasa: se limita a decir al final de la dedicatoria al obispo de Amberes que el Chronicon mundi no había sido impreso anteriormente. Sobre esta edición de Mariana, véase G. Cirot, Mariana historien (Bibliothèque de la Fondation Thiers, VIII. Études sur l'historiographie espagnole), París, 1905. Con relación a la traducción, se conserva una al castellano en un códice de la Real Academia de la Historia fechado en los últimos años del s.XV o primeros del s.XVI, que publicó Puyol, académico de número de dicha institución, en 1926 (J. Puyol, Crónica de España por Lucas, obispo de Tuy. Primera edición del texto romanceado, conforme a un códice de la Academia, preparada y prologada por..., Madrid, 1926).
}

2 Cf. Apologeticus martyrum, 14-16; el texto fue editado hace unos años por el Prof. Juan Gil: Corpus Muzarabicorum, ed. Ioannes Gil, Madrid, 1973, pp. 483-486.

3 Para ello puede verse el artículo de M.C. Díaz Y Díaz, "Los textos antimahometanos más antiguos en códices españoles", Archives d'Histoire doctrinale et littéraire du Môyen Age, 37 (1970), pp. 149-168.

${ }^{4}$ Estoy trabajando en la edición crítica de la obra que aparecerá pronto en el Corpus Christianorum (CC.CM 74). 
De la figura de don Lucas podemos hacer un rápido bosquejo que nos ayude a situar al personaje. Fue diácono y después canónigo de San Isidoro de León, donde quizás habría nacido, y más tarde obispo de Tuy, desde 1239 hasta su muerte en 1249. De su gestión de la sede de Tuy no tenemos muchas referencias; de Tuy don Lucas toma fundamentalmente el nombre y pasa a ser para siempre Lucas de Tuy o el Tudense. Fue fundamentalmente un hombre de su tiempo, un historiador en el sentido que el término tenía en su época, un hombre que escribe en latín su obra, eclesiástico que supo o pudo escalar hasta la dignidad episcopal, infatigable viajero, peregrino a Jerusalén y a Roma ${ }^{5}$.

Entre sus obras ${ }^{6}$ destaca el Chronicon mundi, su gran aportación a la historiografía medieval, compuesto posiblemente antes de 1239. Esta obra, de inspiración isidoriana, comienza por los orígenes del mundo para terminar con acontecimientos de su tiempo, llegando hasta 1236, fecha de la conquista de Córdoba por Fernando IIII. Con ella el Tudense rompe el "largo silencio historiográfico" iniciado con la aparición de la Chronica Adefonsi imperatoris el siglo anterior ${ }^{7}$. A esta obra histórica hay que añadir los Miracula sancti Isidori, buena muestra del género hagiográfico, que también cultivó Don Lucas. Se atribuye también a su pluma la obra De altera uita fideique controuersiis aduersus Albigensium errores libri III, escrita posiblemente cuando todavía era diácono, una obra apologética contra los supuestos albigenses de León.

"Tunc surrexit quidam iniquus concionator ortus in Arabia nomine Mahumet. Qui pessimus seductor uidens inter Orientales et Romanos ortam discordiam, se contra Deum erexit et Christianorum imperium, seductorie ortans gentes Arabum atque dicens, non debere alterius gentis dominio subiugari, quia Dominus illis esset prouisurus de suo genere ducem beniuolum concedendo, quem haberent ut fratrem, cum quo etiam Dominus loqueretur. Hec et his similia cum predicaret illis uerbis suasoriis, et uirtutes quasdam simulatas et miracula artibus magicis facere uideretur, extimplo Hismaelite sicut bruta animalia, quibus non est intellectus, paulatim de bono in malum mutati, derelicta fide catholica ceperunt ei credere et eum in tanta ueneratione habere, ut eum prophetam predicarent a Deo missum, et sibi eligerent regem, simulatis illius seducti miraculis et facundia decepti. Erat enim pulcher, facundus et fortis, et magicis artibus ualde inbutus. Iste Machometus Sarracenorum et Arabum princeps, ut fertur, fuit de genere Ismahel filii Abrahe. Qui cum in adolescencia cepisset esse mercator prouidus,

${ }^{5}$ Los datos fundamentales de la vida de Lucas de Tuy están recogidos en E. Flórez, ES, XXII, 1767, pp. 108 ss. Véase también A. Martínez Casado, "Cátaros en León. Testimonio de Lucas de Tuy", Archivos Leoneses, 37 (1983), pp. 263-311 y J. GIL, "La Historiografía", en Historia de España de R. Menéndez Pidal: La cultura del románico. Siglos XII al XIII, Madrid, 1995, pp. 1-109; "Lucas de Tuy": pp. 88-95.

${ }^{6}$ Para los mss. y las ediciones de las mismas, véase M.C. Díaz y Díaz, Index Scriptorum Latinorum Medii Aevii Hispanorum, Madrid, 1959, pp. 263-264.

7 J.L. Moralejo, "Literatura hispano-latina (Siglos V-XVI)", en J.M. Díez Borque, Historia de las literaturas hispánicas no castellanas, Madrid, 1980, pp. 13-137. 
pergebat frequenter cum camelis suis apud Egiptum et Palestinam, et morabatur cum Iudeis et Christianis, et maxime cum quodam monacho Antioceno supersticionis amico, qui uocabatur Iohannes, a quo tam Nouum quam Vetus superficialiter et supersticiose didicit Testamentum. Et cum hac illacque cum diuersis speciebus aromatum et diuiciarum causa lucri pergeret, contigit ut Corozaniam ingrederetur prouinciam. Cuius prouincie domina, que Hadiga uocabatur, ut uidit iuuenem, primo in illius pulcritudine et eloquencia mente capta, cepit diuersas species quas secum Machometus attulerat, contemplari et ei familiarius aderere. Quam Machumet caute incantacionum suarum perstrinxit fantasmate et astute paulatim cepit ducere in errorem, dicens ei quod ipse esset Messias, quem uenturum expectabant Iudei. Auxiliabantur ei non solum regina Hadiga, que ab eo decepta erat, sed etiam multi Iudeorum qui ad eum de diuersis partibus concurrebant. Omnes etiam Ismahelite et Arabes cateruatim confluebant ad illum, attoniti tanta nouitate rei. Quibus cepit nouas leges fingere, eisque tradere, adibens ipsis nefandis legibus de utroque Testamento corrupta testimonia. Ideo diuine pagine auctoritates peruertit, ut tam Christianis quam Iudeis cum Sarracenis aditum precluderet disputandi. Dedit etiam suis edictum, ut quicumque alia quam ea que ab illo acceperant, predicaret, animaduersione gladii puniretur. Huius sacrilegas tradiciones Sarraceni Dei leges appellant, eumque suum legislatorem et nuncium Dei fatentur. Prefata quoque Hadiga cum uideret illum Iudeorum et Sarracenorum pariter contubernio uallatum, existimabat in illo diuinam latere potenciam, et cum esset uidua, accepit eum sibi maritum, et ipse Mahumeth nomen regis assumpsit sibi imposito diademate regni. Cepit deinde se in armis gerere strenue et regis ac prophete sibi nomen et insignia usurpare. Post hec uero cepit cadere frequenter caduco morbo et epilentica passione. Quod regina Hadiga cernens admodum tristabatur, eo quod nupsisset homini quem credebat arreptione demonum laborare. Ille autem astute leniendo decipiebat eam dicens: 'quia angelum Domini Gabrielem mecum loquentem contemplor, et non ferens splendorem uultus eius, utpote carnalis homo, deficio et cado'. Hec dicens, quedam signa et miracula magicis artibus facere nitebatur. Verumtamen, ut fertur, diabolus transfigurans se in angelum lucis, quedam ei predicebat futura. Vnde est ut in exordio sue subdole predicationis adiret Yspaniam et Cordube sue perditionis sectam doceret. Dicebat enim Ihesum Christum Dominum de Virgine esse natum operatione Spiritus Sancti, non tamen esse Deum. Quod cum beatissimo patri Ysidoro nunciatum fuisset, qui tunc reuertebatur a Romana curia, confestim misit ministros qui caperent eum. Sed diabolus Machometo aparuit et quam cicius fugeret, imperauit. Machometus autem post fugam in Affricam et Arabiam innumerabiles plebes seduxit, et regno adepto, cum Hismaelitis qui credebant eum ab ore Gabrielis archangeli leges quas eis tradebat, recipere, Romanum imperium fortiter deuastabat.

Era DC.L.VI. Machometus cum exercitu suo partes Arabie, Syriam et Mesopotamiam hostiliter inuasit, et tam ipsas quam uicinas patrias funesta depredatione occupauit. Quod cum nunciatum fuisset Theodoro, fratri Eraclei, qui tunc preerat partibus Orientis, mox apud Gabatam cum magno exercitu obuiam illi preliaturus occurrit; ubi, dum inter se acrius dimicarent, Theodorus interfectus est, et exercitus Christianorum maxima pars occubuit diro gladio et ceteri fuga lapsi sunt. Tunc Agareni de Romanorum fuga ualidiores effecti audacius appetunt Syriam, et depopulantes patriam apud Damascum nobilem condam Christianorum urbem, sibi regni solium firmauerunt, et dictis Machometi tribuebant fidem, diuinam in eo 
latere potenciam asserentes. Machometus autem inter cetera nefanda que docuit, sectam Nicholay aduene Antiocheni, qui unus de septem Apostolorum diaconis fuerat, iam per Apostolos emortuam suscitauit, quam Dominus in Apocalipsi angelo Ephesi ecclesie scribit se odire dicens: 'Odisti facta Nicholaytarum, que et ego odi'. Decimo autem regni sui anno, quia dixerat se moriturum et tercia die resurrecturum, Albimor discipulus eius uolens experiri utrum uere a morte resurgeret, callide Machometo efficacissimum uenenum obtulit, quo statim repentina mutatione Machumet mortis sue terminum sensit. Vnde quibusdam sibi astantibus dixit quod per aquam remissionem acciperent peccatorum, et statim mortuus est. Discipuli uero eius diligenter custodiebant corpus ipsius, expectantes quod resurgeret. Sed nimio erumpente fetore, cumiam sustinere non possent, eis abscedentibus Albimor post undecimam diem reperit corpus eius a canibus dilaniatum, et diligenter colligens ossa illius cum magno Sarracenorum conuentu sepeliuit eum in Medina Rassul, que Latine Ciuitas Nuncii dicitur".

"Surgió entonces un inicuo demagogo, nacido en Arabia, de nombre Mahoma. Este pésimo seductor, al ver que había nacido la discordia entre los orientales y los romanos, se alzó contra Dios y el señorío de los cristianos, arengando con sus seductoras artes a los árabes y diciendo que no debían someterse al dominio de otro pueblo, porque el Señor habría de velar por ellos concediéndoles un jefe estimado, nacido de su propia raza, a quien tendrían por hermano y con quien hablaría el Señor. Como predicara estas cosas y otras semejantes con aquellas persuasivas palabras y pareciera fingir algunas virtudes y hacer milagros por medio de artes mágicas, al punto los ismaelitas como brutos animales que no tienen entendimiento, tras cambiar poco a poco del bien al mal, una vez abandonada la fe cristiana, empezaron a creerle y a tratarle con tan gran veneración que decían que era un profeta enviado por Dios y le hicieron rey, seducidos por sus fingidos milagros y engañados por su elocuencia. Pues era guapo, fuerte, hablaba bien y era buen conocedor de las artes mágicas. Este Mahoma, príncipe de los sarracenos y de los árabes, según se dice, fue del linaje de Ismael, el hijo de Abraham. El cual, como había comenzado a ser mercader en su juventud, con frecuencia iba con sus camellos hasta Egipto y Palestina, y vivía con judíos y cristianos, especialmente con un monje de Antioquía, interesado en su falsa fe, que se llamaba Juan, de quien aprendió tanto el Nuevo como el Antiguo Testamento de forma superficial y errónea. Y yendo de acá para allá con diversas clases de perfumes y riquezas para ganar dinero, sucedió que llegó a la provincia Corozania. La señora de esta provincia, que se llamaba Hadiga, cuando vió al joven, prendada en primer lugar de su belleza y elocuencia, empezó a mirar las diferentes mercancías que había traIdo Mahoma consigo y a tratarle con más familiaridad. Mahoma cautamente la ató con sus fingidos encantamientos y con astucia poco a poco la arrastró al error, diciéndole que él era el Mesías que esperaban los judíos que habría de venir. Le ayudaban no sólo la reina Hadiga, que había sido inducida al error por él, sino también muchos judíos que llegaban hasta él desde distintas partes. Pues todos los ismaelitas y árabes acudían a aquél en bandadas, atónitos por la novedad del asunto. Para éstos comenzó a imaginar y dar nuevas leyes, añadiendo a estas nefandas leyes corruptos testimonios de ambos Testamentos, por lo que trastornó la autoridad de la Sagrada Escritura, de manera que cerró la posibilidad de disputar con los sarracenos tanto 
a los cristianos como a los judíos. También dio a los suyos un edicto, para que todo el que predicara otra cosa distinta a lo que había aprendido de él, fuese castigado con la pena de muerte. A las sacrílegas tradiciones de éste los sarracenos las llaman leyes de Dios y a él lo tienen por su legislador y mensajero divino. La mencionada Hadiga viendo que él estaba rodeado al mismo tiempo por la amistad de judíos y sarracenos, pensaba que se escondía en él una fuerza divina y, como era viuda, lo recibió como marido; el propio Mahoma asumió el título de rey después de haberle sido impuesta la corona real. Luego comenzó él a tomar valerosamente las armas y a usurpar el nombre y las insignias de rey y de profeta. Pero después de ésto, comenzó a sufrir con frecuencia ataques de epilepsia. Viéndolo la reina Hadiga se entristecía mucho, porque creía que se había casado con un hombre que estaba endemoniado; pero él, calmándola astutamente, la engañaba diciendo: "Porque contemplo al ángel del Señor, Gabriel, que habla conmigo, no puedo soportar el resplandor de su cara y, como hombre carnal, desfallezco y caigo". Diciendo esto, se esforzaba por hacer algunos milagros y señales con artes mágicas, y, según se dice, el diablo transfigurándose en ángel de luz, le predecía cosas futuras. De esta manera, al comienzo de su engañosa predicación se dirigió a Hispania y fundó una secta de su desgraciada religión en Córdoba. Pues decía que el Señor Jesucristo había nacido de la Virgen por obra del Espíritu Santo, pero que no era Dios. Como le hubiera sido anunciado esto al santísimo padre Isidoro, que entonces regresaba de la curia romana, al instante envió ministros para prenderlo. Pero el diablo se apareció a Mahoma y le ordenó que huyera lo más rápidamente posible. Éste, después de huir a África y a Arabia, sedujo innumerables pueblos y, alcanzado el poder, atacó a los romanos intrépidamente con los ismaelitas, que creían que él recibía de boca del arcángel Gabriel las leyes que les daba.

En la era 656 [año 618] Mahoma irrumpió hostilmente con su ejército en las regiones de Arabia, Siria y Mesopotamia, y ocupó con funesta depredación tanto éstas como las tierras vecinas. Como le hubiera sido anunciado esto a Teodoro, hermano de Heracleo, que entonces estaba al frente de las regiones de Oriente, le salió al encuentro para pelear con un gran ejército en Gabata, donde, como luchasen ferozmente, Teodoro fue muerto y el ejército de los cristianos en gran parte sucumbió de cruel muerte y los restantes se dieron a la huida. Entonces los agarenos, envalentonados por la huida de los romanos, más audazmente atacaron Siria y devastando aquella tierra asentaron su reino en Damasco, noble ciudad que fue en otro tiempo de los cristianos; daban crédito a las palabras de Mahoma diciendo que en él se escondía un poder divino. Pero éste, entre otras cosas nefandas que enseñó, reanimó la secta del ignorante Nicoalo de Antioquía, quien había sido uno de los siete diáconos de los apóstoles, la cual en época de aquéllos estaba extinguida y de la que el Señor en el Apocalipsis escribió al ángel de la iglesia de Efeso diciendo que la odiaba: "Detestas el proceder de los nicolaítas, que yo también detesto"8. Pero al décimo año de su reinado, puesto que había dicho que él moriría y que resucitaría al tercer día, su discípulo Albimor, queriendo comprobar si realmente resucitaría de la muerte, hábilmente le proporcionó un veneno muy eficaz a Mahoma. Éste dijo a algunos que estaban presentes, que recibirían el perdón de los pecados por medio del agua 
y en seguida murió. Sus discípulos guardaban su cuerpo esperando que resucitase, pero como despedía tan gran hedor y ya no podían soportarlo, se marcharon; Albimor después de once días encontró su cuerpo despedazado por los perros y, tras recoger rápidamente sus huesos, con gran acompañamiento de sarracenos, lo enterró en Medina Rassul, que en latín quiere decir "ciudad del mensajero". 